\title{
ON THE (IN)DEFINITENESS OF IMPERSONAL PRONOUNS**
}

\section{INTRODUCTION}

Although the cross-linguistic variation found for possible uses of impersonal pronouns is quite well-studied, open questions on their semantic analysis remain. One persistent point of contention is whether impersonal pronouns - based on their semantic/pragmatic behaviour - should be analyzed as definite or indefinite expressions. Practically all possible answers to this question have been argued for. They have been analyzed as definite expressions (e.g., Kratzer 1997; Alonso-Ovalle 2002), as indefinite(-like) expressions (e.g., Condoravdi 1989; Moltmann 2012; Malamud 2013), and as "a-definites" (Koenig \& Mauner 1999).

The main aim of this paper is to add new empirical facts to the discussion, which, to my mind, tip the scales in favour of Koenig \& Mauner's claim that impersonal pronouns cannot be grouped with either definite or indefinite NPs. The empirical investigation is conducted using the German impersonal pronoun man, specifically, its existential use ("existential man").

Like all impersonal pronouns cross-linguistically, German man has a generic use, as in (1).

(1) Man muss seine Eltern respektieren.

(German)

MAN has-to his parents respect

'One has to respect one's parents.'

This use occurs exclusively in generic sentences - sentences stating a rule or nonaccidental regularity. The existential use of man is given in (2).

(2) Gestern hat man die Uni angezündet.

yesterday has MAN the uni set-on-fire

$\approx$ 'Yesterday, someone set the university on fire.'

This use occurs only in episodic sentences - sentences describing a specific situation/eventuality, including accidental generalizations. ${ }^{1}$ Unlike the generic use, the

* sarah.zobel@ds.uni-tuebingen.de

** I thank the audiences of Pronouns@Tübingen 2 and SinFonIJA 8 and two anonymous reviewers for helpful comments and suggestions. All mistakes are my own.

1 Accidental generalizations cannot be used to make predictions about other individuals and are usually expressed by extensional quantification, e.g., with nominal quantifiers: "Every student in 
existential use is not uniformly available. English one, for instance, lacks this use. $^{2}$

This investigation focuses exclusively on existential man since the generic use is inseparably tied to the intensional, quantificational generic operator Gen. Since definite and indefinite singular NPs interact with Gen in different ways (see Krifka et al. 1995), similarities in the semantic/pragmatic behaviour of man and these NPs are always masked by Gen (Zobel 2014).

The paper is structured as follows. In Section 2, I present new data on the discourse anaphoric potential (DAP) of impersonal pronouns as compared to (in) definite NPs. In Section 3, I show that the DAP of existential man is comparable to that of implicit agents of short passives - as Koenig \& Mauner (1999) argued for French $o n \cdot{ }^{3}$ Section 4 discusses quantificational variability effects (QVE) with man. QVE is seen as the most robust argument for classifying man as an indefinite (see Malamud 2013). Section 5 sketches the core idea for a semantic analysis of man based on Onea $(2013,2015)$. Section 6 concludes the paper.

\section{THE DAP OF (IN)DEFINITE NPS AND EXISTENTIAL MAN}

The question whether impersonal pronouns are definite or indefinite expressions is not discussed in the literature with respect to a single, specific theory of (in)definiteness (see Heim 2011 for a recent overview). The central question, also pursued in this paper, is whether the semantic/pragmatic behaviour of impersonal pronouns is comparable to that of definite or indefinite NPs, or whether they are distinct from either.

The aspect of the semantic/pragmatic behaviour of man that I focus on is the discourse anaphoric potential (DAP) of existential man. That is, for which kinds of anaphoric nominal elements existential man can be an antecedent, and conversely, the referents of which nominal elements can be taken up by existential man. The DAP of (in)definite NPs is very well studied (see Heim 2011); the data on the DAP of existential man is still incomplete (see Cabredo-Hofherr 2010; Malamud 2013 for previous results).

As English one lacks an existential use, existential man is usually translated as someone (see (2)). This translation is inadequate. The scope behaviour of existential man is not comparable to that of indefinite pronouns: existential man, unlike indefinite pronouns, always takes narrow scope with respect to other quantifiers (Zifonun 2000). Based on the data presented below, I argue that it denotes an indeterminate "group" of individuals (possibly a single person), which I label "X". Which individuals the speaker means by " $X$ " can, in the right contexts, be inferred.

my class wears a t-shirt". Non-accidental generalizations arguably involve intensional quantification (see Greenberg 2007).

2 French on (see Koenig \& Mauner 1999; Cabredo-Hofherr 2010) and Italian si (see Cinque 1988) among other European languages behave like German man. Spanish uno and Icelandic maður, for instance, pattern with English one (Cabredo-Hofherr 2010).

3 Koenig \& Mauner (1999) do not explicitly restrict their claim to the existential readings of impersonal pronouns, but they only discuss examples of existentially used French on. 


\subsection{The DAP of Existential Man across Sentence Boundaries}

The DAP of (in)definite NPs across sentence boundaries is summarized in (3).

(3) a) Indefinite NPs can occur discourse initially and can serve as antecedents for strictly anaphoric expressions (i.e., definite NPs and personal pronouns). They cannot take up discourse referents (DRs) that have been previously introduced.

b) Definite NPs are marked discourse initially. They can serve as antecedents for other strictly anaphoric expressions and can take up DRs that have been previously introduced.

Like indefinite but unlike definite NPs, existential man can occur discourse initially. ${ }^{4}$ That is, the group X does not have to be previously introduced. In this case, existential man is intuitively interpreted similar to an indefinite pronoun.

(4) Hast du das gehört? Gestern hat man die Uni angezündet. have you that heard yesterday has MAN the uni set-on-fire 'Did you hear? Yesterday, $\mathrm{X}$ set the university on fire.' $\quad(\mathrm{X} \approx$ someone $)$

Unlike definite and indefinite NPs, though, $\mathrm{X}$ cannot be taken up by 3rd sg. pronouns or arbitrary singular definite descriptions (see Cabredo-Hofherr 2008; Zifonun 2000). None of the expressions in subject position in (5) can refer back to $X$ denoted by $\operatorname{man}$ in (4).

\section{(5) \#Der Mann / er / sie hat ein Streichholz in einen Mülleimer geworfen. the man / he/she has a match in a garbage-can thrown 'The man / he / she threw a match in a garbage can.'}

The group X in (4) can, however, be taken up by (i) 3rd pl. personal and demonstrative pronouns with a corporate/bridging reading, ${ }^{5}$ (ii) bridging definite NPs (see Schwarz 2009), and (iii) existential man. This is illustrated in (6) (= i \& ii) and (7) (= iii), which can both continue (4). ${ }^{6}$

4 The judgments given on the German data are based on my own native speaker judgments and judgments of three native speaker informants (of different varieties) on constructed and naturally occurring examples. Experimental evidence is still to be gathered.

5 Koenig \& Mauner (1999) call the corporate reading of 3rd person plural personal pronouns their "indefinite use". I prefer the more theoretically neutral term "corporate/bridging reading" since it is not clear that the pronouns in this use are indeed indefinite (see Malamud 2013; Grosz 2016).

6 Malamud (2013) argues that the cases illustrated in (6) are impossible for German man. Her claim is based on the result of a corpus study: her sample (100 occurrences of man) did not contain any examples of this kind. However, 100 tokens of man are too few to establish all potential continuations for man, and existential man is itself quite rare. 
(6)

Sie / die / die Brandstifter haben ein Streichholz in einen Mülleimer geworfen. they/d-pron/the arsonists have a match in a garbage-can thrown 'They / they / the arsonists threw a match in a garbage can.'

\section{(7) Man hat ein Streichholz in einen Mülleimer geworfen. MAN has a match in a garbage-can thrown ' $\mathrm{X}$ ' threw a match in a garbage can.'$$
\left(X^{\prime} \rightarrow X\right. \text { of (4)) }
$$

The expressions in (6), which intuitively refer to $X$ in (4), are not strictly anaphoric to it. The perceived "reference sharing", I argue, is the result of inference. This is supported by the different number specifications of man (sg.) and sie/dieldie Brandstifter (pl.); strictly anaphoric expressions (e.g., co-referring personal pronouns and definite NPs) always agree with their antecedents in person and number. ${ }^{7}$

Subsequent occurrences of existential man may but do not have to refer back to the group of individuals given by a preceding occurrence of existential man. Example (9) can continue (4), just like (8).

(8) Man sucht noch nach den Brandstiftern. MAN searches still for the arsonists ' $\mathrm{X}$ ' is still looking for the arsonists.'

$$
\left(\mathrm{X}^{\prime \prime} \rightarrow\right. \text { the police) }
$$

Since the group understood for existential man in (4), the arsonists, are explicitly referred to in (8), another group of individuals has to be inferred for man in (8). World knowledge suggests that the people looking for the arsonists are most plausibly the police.

Lastly, existential man can be interpreted as denoting previously introduced DRs, as in (9). This possibility is only shared by definite NPs.

Eine Gruppe von Studenten ist für ihren Vandalismus bekannt. Gestern hat man zum a group of students is for their vandalism known yesterday has MAN for Beispiel die Uni angezündet.

example the uni set-on-fire

'A group of students is known for their vandalism. For example, yesterday $\mathrm{X}$ set the university on fire.'

( $\mathrm{X} \rightarrow$ the group of students)

In (9), zum Beispiel (Engl.'for example') signals that the second sentence takes up the subject matter of the preceding sentence. Hence, the group of students introduced

7 One counterexample to this rule are split antecedents, see (i). Example (4) does not provide the right setup to argue that sie (Engl. 'they') has a split antecedent, though.

(i) Every boy/Peter has asked some girls/Mary if they could go out on a date. (see Büring 2011: 988) 
in the first sentence is a plausible candidate for the agents of the second sentence $(=\mathrm{X})$. Crucially, the speaker in (9) does not explicitly claim that the group of students is responsible for setting the university on fire, which would be the case if she had used the strictly anaphoric 3rd pl. personal pronoun sie (Engl. 'they'). This, I argue, is a result of determining the specification of $\mathrm{X}$ via inference.

In general, highly topical or salient DRs can be inferred as "referents" of man - provided that the discourse relations that link the utterances, as in (9), do not discourage this inference (see Asher \& Lascarides 2003 on discourse relations).

\subsection{The DAP of Existential Man Sentence Internally}

Existential man can "co-refer" with (i) the 3rd singular reflexive sich, (ii) PRO, and (iii) existential man, but, again, not with personal pronouns or definite NPs (CabredoHofherr 2008; Zifonun 2000). ${ }^{8}$ For (in)definite NPs, no such restrictions obtain. Possibilities (i) and (ii) are illustrated in (10).

(10) Man hat sich entschlossen PRo zu bleiben.

MAN has SELF decided PRO to stay

'X decided to stay.'

(= X decided that $\mathrm{X}$ stays $)$

The possibility of reflexivization and control for existential man is not a counterargument against the claim that man cannot co-refer with strictly anaphoric expressions. Here I follow Chierchia (1995) and Landau (2010) in assuming that reflexivization and control do not involve co-reference.

Multiple occurrences of existential man in multi-clausal sentences (possibility (iii) above) can again be read either as referring to the same group or a larger group of individuals, or as referring to two (not necessarily overlapping) groups, as in (11). The former reading is preferred.

(11) Man hat hoffnungsvoll gefragt, ob man sich morgen trifft. MAN has hopeful asked whether MAN SELF tomorrow meets ' $\mathrm{X}$ asked hopeful whether $\mathrm{X}$ ' are meeting up tomorrow.'

\subsection{Interim Summary}

From Sections 2.1 and 2.2, I conclude that existential man and (in)definite NPs differ as follows:

- Indefinite NPs always introduce new DRs and, hence, cannot refer to DRs that were previously introduced.

- Definite NPs (almost) always refer to DRs that were previously introduced.

8 For existential man, the suppletive forms einen (acc.) and einem (dat.) - inflected forms of the indefinite pronoun einer (Engl. 'someone') - are not available, and existential man cannot "corefer" with possessives; both is possible for generically used man (see Kratzer 1997). An investigation of this issue has to be left for future research. 
- Existential man never introduces new DRs that could be referred to by anaphoric expressions, and cannot refer to DRs that were previously introduced.

As Condoravdi (1989), Moltmann (2012), and Malamud (2013), among others, argue, man contributes a free variable that is, in the generic use of man, unselectively bound by Gen. If this idea is to be extended to existential man, one has to find a way to distinguish variables, which are needed to model quantification, from $D R s$, which are needed to model anaphoric relations, and find a way to connect these two appropriately. The core idea for an analysis with these features is sketched in Section 5.

\section{EXISTENTIAL MAN AND IMPLICIT AGENTS}

The data on the DAP of existential man given in Section 2 mirrors the DAP of German implicit agents of short passives (IAP), which are "strong implicit arguments" (Landau 2010). IAPs in German can occur discourse initially, as in (12a), but cannot be taken up in a subsequent sentence by strictly anaphoric expressions, as in (12b).

(12) a) Der Uni wurde IAP abgefackelt.

the uni was IAP set-on-fire

'Someone set the university on fire.'

b) \#Der Mann / er / sie hat Benzin verwendet.

the man / he/she has gas used

'The man / he / she used gas.'

The IAP in (12a) can be picked up by bridging definites and corporate/bridging pronouns, as in (13), as well as another IAP, as in (14).

(13) Die Täter / sie haben Benzin verwendet.

the offenders / they have gas used

'The offenders / they used gas.'

(14) Es wurde IAP Benzin verwendet.

it was IAP gas used

'They used gas.'

Sentence-internally, IAPs can control PRO and "co-refer" with reflexive sich, as in (15), see Alexiadou \& Müller 2015.

(15) a) Es wurde IAP beschlossen PRo Benzin zu verwenden.

it was IAP decided PRO gas to use

$(\approx$ Someone/X decided to use gas. $)$

b) Hier wurde IAP sich nicht geprügelt.

here was IAP SELF not hit

$\approx$ 'No one hit each other here.' 
In sum, this strong parallel in the DAP of existential man and IAPs suggests that they should indeed be analyzed similarly (pace Malamud 2013). Koenig \& Mauner (1999) observe the same characteristics for French IAPs and the impersonal pronoun on. They introduce the notion of "a-definites" in (16) to refer to expressions with this DAP (compare to Section 2.3).

(16) A-definites are expressions that are "inert in discourse": they cannot serve as the anchor of an anaphoric element - unless the perceived anaphoricity is the result of lexical or inferential processes. (Koenig \& Mauner 1999: 213, 220ff)

\section{IMPERSONAL PRONOUNS AND QVE}

As the main argument for classifying impersonal pronouns as indefinite-like expressions, the observation is usually given that impersonal pronouns show "classical" quantificational variability effects (QVE) with adverbs of quantification like often, usually, or seldom (see Malamud 2013), which do not occur with singular definite expressions (see Hinterwimmer 2008). Example (17) illustrates classical QVE with German man and English one. ${ }^{9}$

(17) An dieser Fakultät $\quad$ ist man normalerweise klug. $\quad(\approx$ Malamud 2013:14) at this department is MAN usually smart 'In this department, one is usually smart.' $\left(\approx_{\mathrm{QVE}}\right.$ Most members of this department are smart.)

In addition, Malamud (2013: 26) observes that English IAPs show only QVE-like effects with for the most part, as in (18). Such QVE-like effects have been reported to occur only with plural definite expressions (Nakanishi \& Romero 2004)..$^{10}$

(18) In Spain, Michael Jackson is for the most part admired. (Malamud 2013: 21) $\left(\approx_{\mathrm{QVE}}\right.$ Most Spaniards admire Michael Jackson.)

Hence, the availability of QVE vs. QVE(-like) effects apparently differentiates impersonal pronouns from implicit agents. That is, the result of Section 3 that existential man and IAPs show parallel behaviour seems to be incorrect.

However, this conclusion is premature. Firstly, there are cases of classical QVE with German IAPs: (19) can be interpreted as stating that the majority of implicit agents (i.e., doctors/researchers) assume the given list of reasons. That is, üblicherweise (Engl. 'usually') quantifies over implicit agents.

9 All sentences for which I claim an availability of QVE or QVE(-like) effects also have a second interpretation for which the adverb of quantification quantifies over times, situations, or parts.

10 Alexiadou \& Müller (2015) also observe QVE-like effects for German IAPs. 
(19) Zu den Ursachen des Herzinfarkts werden üblicherweise [...] gezählt. to the reasons of-the heart-attack will usually [...] counted $\left(\approx_{\text {QVE }} \text { Most doctors/researchers count }[\ldots] \text { among the reasons for a heart attack. }\right)^{11}$

Secondly, existential man also shows QVE-like effects with größtenteils (Engl. 'for the most part').

(20) [Context: Newspaper article on a theatre performance in a local park.] Man war größtenteils in legerer Sommerkleidung gekommen. MAN was for-the-most-part in casual summer-dress come 'For the most part, $\mathrm{X}$ had appeared in casual summer dress. ${ }^{12}(\mathrm{X} \rightarrow$ the audience $)$ $\left(\approx_{\text {QVE }}\right.$ Most people in the audience had appeared in casual summer dress. $)$

Together, (17) and (20) would imply that man has to be classified and analyzed as both indefinite and definite, which is an undesirable result. I believe that the possibilities regarding QVE vs. QVE-like effects vary with the uses of man. For reasons of space, further details have to be left for another occasion. The upshot is that the possibility of QVE with man is not air-tight evidence that man is an indefinite(-like) expression.

\section{SKETCHING A FORMAL ANALYSIS FOR MAN}

To capture the DAP of existential man, we need a formal system that can distinguish between variables and DRs (see Section 2.3). While the formal system proposed in (Onea 2013, 2015) is not explicitly designed to do this, it can be extended to capture this distinction.

In Onea's $(2013,2015)$ system $^{13}$, all lexical entries take assignment functions as arguments. "Referential expressions" (i.e., (in)definite NPs, proper names, pronouns) place constraints on these assignments. A proper name like Peter, as in (21), contributes the value $h(i)$ (= an individual) returned by the assignment argument $h$ for its index $i$, provided that the restriction on the assignment, $h(i)=$ Peter, is met.

$$
\left[\left[\text { Peter }_{i}\right]\right]^{\mathrm{w}}=\lambda \mathrm{h}[\mathrm{h}(\mathrm{i})=\text { Peter }] . \mathrm{h}(\mathrm{i})
$$

A sentence like Peter laughs is assigned the denotation in (22), which is true for an assignment $h$ iff $h(i)=$ Peter and $h(i)$ is laughing in $w$. The restriction on compatible assignments contributed by Peter in (21) is inherited by the full sentence.

$$
\left[\left[\text { Peter }_{i} \text { laughs }\right]\right]^{\mathrm{w}}=\lambda \mathrm{h}[\mathrm{h}(\mathrm{i})=\text { Peter }] \text {. laugh }(\mathrm{h}(\mathrm{i}))(\mathrm{w})
$$

11 http://www.zeit.de/1966/51/wie-entsteht-der-herzinfarkt (last accessed: Aug 25, 2016)

12 http://www.nwzonline.de/cloppenburg/kultur/maerchen-in-schrillen-kostuemen_a_ 30,0,1014137318.html (last accessed: Aug 25, 2016)

13 For reasons of space, I cannot discuss the system in more detail. I refer the interested reader to the original works. 
In this system, quantification and binding both utilize the assignment arguments. Quantifiers quantify over sets of assignments; pronouns denote the output that their assignment argument provides for the index that they bear, as in (23).

$$
\left[\left[\operatorname{pron}_{\mathrm{i}}\right]\right]^{\mathrm{w}}=\lambda \mathrm{h} \cdot \mathrm{h}(\mathrm{i})
$$

Onea's system is only designed to handle inter-sentential binding and anaphora. To model cross-sentential anaphora, I extend it by a parameter $G$, which records the active DRs.

$G$ is a set of assignment functions. At the start of the conversation, $G$ equals the set of all assignment functions $A$. Each subsequent sentence reduces this set. For instance, the denotation of Peter laughs in (22) removes all assignment functions in $G$ that do not output Peter for the index $i$ or for which the individual returned for $i$ does not laugh in $w$.

For man, I assume that it has the same denotation as anaphoric pronouns, as in (23), which is equivalent to assuming that man contributes a free variable in more familiar static systems.

$$
\left[\left[\operatorname{man}_{\mathrm{i}}\right]\right]^{\mathrm{w}, \mathrm{G}}=\lambda \mathrm{h} . \mathrm{h}(\mathrm{i})
$$

To ensure that existential man does not access or restrict the set $G$ (i.e., does not access or contribute a DR), we need to assume that it is bound by a selective variant of existential closure at the VP level (Onea 2015). The denotation of Man hat gelacht (Engl. $\approx$ 'Someone laughed') is as in (25).

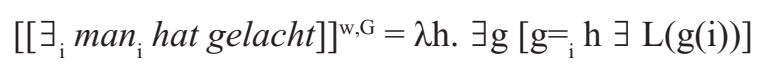

The selective existential closure operator $\exists_{\mathrm{i}}$ in (25) introduces existential quantification over assignments $g$ that are identical to the assignment argument $h$ except for the output for the index $i(g=h)$. Since only the restrictions placed on $h$ will constrain $G$, this means that any content that is predicated of $g(i)$ will not access or add restrictions to $G$. Conceptually, this ensures that existential man cannot refer to existing DRs or introduce new DRs, as desired.

The generic use of man is captured by assuming that man is bound by Gen at the sentence level (see Condoravdi 1989; Moltmann 2012; Malamud 2013), and QVE with man can be modeled by assuming that it is bound by an adverb of quantification (see Malamud 2013). For reasons of space, I cannot present this proposal and its implications in any more detail.

\section{CONCLUSION}

I have shown that the DAP of existential man differs from that of indefinite and definite NPs, but is parallel to that of German IAPs, which can be classified as "a-definites" following Koenig \& Mauner (1999). Furthermore, I showed that using the availability 
of QVE as an argument for the claim that impersonal pronouns are indefinite is not as straightforward as has been previously claimed. Lastly, I sketched a formal analysis that can capture the DAP of existential man outlined in this paper.

\section{References}

ALEXIADOU, Artemis/Gereon MÜLLER (2015) "Passive Operations: The External Argument." Poster presented at Sinn und Bedeutung 20, University of Tübingen. ALONSO-OVALLE, Luis (2002) "Arbitrary Pronouns Are Not That Indefinite." In: C. Beyssade et al. (eds), Romance Languages and Linguistic Theory 2000. John Benjamins, 1-15.

ASHER, Nicholas/Alex LASCARIDES (2003) Logics of Conversation. Cambridge: Cambridge University Press.

BÜRING, Daniel (2011) "Pronouns." In: C. Maienborn et al. (eds), Handbooks of Linguistics and Communication Science (HSK) 33/2. Berlin/New York: DeGruyter, 971-996

CABREDO-HOFHERR, Patricia (2008) "Les pronoms impersonnels humains - syntaxe et interprétation." Modèles linguistiques tome XXIX-1/57, 35-56.

CABREDO-HOFHERR, Patricia (2010) "Binding properties of impersonal human pronouns in generic and episodic contexts." Handout presented at the Workshop on impersonal pronouns, May 28, Paris. http://archive.sfl.cnrs.fr/sites/sfl/IMG/pdf/ impersMay2010CabredoHofherrManOnLa.pdf

CHIERCHIA, Gennaro (1995) “The Variability of Impersonal Subjects.” In: E. Bach et al. (eds), Quantification in Natural Languages. Springer, 107-143.

CINQUE, Guglielmo (1988) "On si constructions and the theory of arb." Linguistic Inquiry 19, 521-582.

CONDORAVDI, Cleo (1989) "Indefinite and generic pronouns." In: E. Jane Fee/K. Hunt (eds), Proceedings of the Eigth West Coast Conference on Formal Linguistics. Stanford, CA: Center for the Study of Language and Information, 71-84.

GREENBERG, Yael (2007) "Exceptions to generics: Where vagueness, context dependence and modality interact." Journal of Semantics 24, 131-167.

GROSZ, Patrick (2016) Bridging uses of demonstrative pronouns in German. Ms. University of Oslo.

HEIM, Irene (2011) "Definiteness and indefiniteness." In: K. von Heusinger/C. Maienborn/P. Portner (eds), Semantics, Volume 2. Berlin/Boston: De Gruyter Mouton, 996-1025.

HINTERWIMMER, Stefan (2008) Q-Adverbs as Selective Binders: The Quantificational Variability of Free Relatives and Definite DPs. Berlin/New York: De Gruyter.

KOENIG, Jean-Pierre/Gail MAUNER (1999) "A-definites and the Discourse Status of Implicit Arguments.” Journal of Semantics 16, 207-236.

KRATZER, Angelika (1997) "German impersonal pronouns and logophoricity." Presentation at Sinn und Bedeutung II. Berlin, Germany. semanticsarchive.net.

KRIFKA, Manfred et al. (1995) "Genericity: an introduction." In: G. Carlson/F.J. Pelletier (eds), The Generic Book. Chicago: University of Chicago Press, 1-124. 
LANDAU, Idan (2010) "The explicit syntax of implicit arguments." Linguistic Inquiry 41, 357-388.

MALAMUD, Sophia A (2013) "(In)definiteness driven typology of arbitrary items." Lingua 126, 1-31.

MOLTMANN, Friederike (2012) "Two kinds of first-person-oriented content." Synthese 184, 157-177.

NAKANISHI, Kimiko/Maribel ROMERO (2004) "Two constructions with most and their semantic properties." In: K. Moulton/M. Wolf (eds), Proceedings of the North East Linguistic Society 34/2. Amherst: University of Massachusetts at Amherst, 453-468.

ONEA, Edgar (2013) "Indefinite donkeys on islands." In: Todd Snider, Proceedings of SALT 23, University of California, Santa Cruz, 493-513. http://dx.doi.org/10.3765/ salt.v23i0.2666.

ONEA, Edgar (2015) "Why indefinites can escape scope islands." Linguistics and Philosophy 38, 237-267.

SCHWARZ, Florian (2009) Two Types of Definites in Natural Language. Amherst: University of Massachusetts at Amherst.

ZIFONUN, Gisela (2000) "Morphosyntax und Semantik des Pronomens "man"." Deutsche Sprache 28, 232-253.

ZOBEL, Sarah (2014) Impersonly Interpreted Personal Pronouns. University of Göttingen. http://hdl.handle.net/11858/00-1735-0000-0023-991B-2

\section{Summary \\ ON THE (IN)DEFINITENESS OF IMPERSONAL PRONOUNS}

This paper addresses the question whether impersonal pronouns should be analyzed as indefinite or definite expressions based on their discourse anaphoric potential. I present new data that support the claim that impersonal pronouns should be analyzed as neither (see Koenig \& Mauner 1999). I sketch a formal analysis that captures this behaviour. Furthermore, I show that the availability of quantificational variability effects for impersonal pronouns is not foolproof evidence for their indefiniteness as is usually assumed in the literature (see Malamud 2013).

Keywords: impersonal pronouns, German, man, existential use, discourse anaphoric potential

\section{Povzetek \\ O (NE)DOLOČNOSTI NEOSEBNIH ZAIMKOV}

V članku se ukvarjamo z vprašanjem, ali naj neosebne zaimke glede na njihov diskurzivni anaforični potencial analiziramo kot nedoločne ali določne izraze. Predstavimo nove podatke, ki govorijo $\mathrm{v}$ prid trditvi, da neosebni zaimki ne spadajo $\mathrm{v}$ nobeno od obeh kategorij (glej Koenig/Mauner 1999). Predlagamo formalno analizo, ki odraža to 
njihovo vedenje. Poleg tega pokažemo, da prisotnost učinkov kvantifikacijske variabilnosti v primeru neosebnih zaimkov ni neizpodbiten dokaz za njihovo nedoločnost, kot se običajno predpostavlja v literaturi (cf. Malamud 2013).

Ključne besede: neosebni zaimki, nemščina, man, bivanjska raba, diskurzivni anaforični potencial 